DOI: https://doi.org/10.31392/NZ-npu-145.2019.23

УДК 378.091 .27

Шевчук Л. Д., Яшанов С. М.

\title{
ТЕОРЕТИЧНІ ТА МЕТОДОЛОГІЧНІ АСПЕКТИ ПЕДАГОГІЧНОГО КОНТРОЛЮ ЗНАНЬ СТУДЕНТІВ НА ОСНОВІ ТЕСТОВОї ТЕХНОЛОГІї
}

У статті розглянуто питання теорї $і$ методологї педагогічного контролю знань студентів на основі тестової технології. Обірунтовано рекомендації щуодо організації процесу тестового контролю знань. Підкреслено, щуо тестові технології заслуговують на особливу увагу, адже изе ефективний спосіб перевірки рівня якості знань студентів. Подано пропозиції щзодо вирішення проблеми якості контролю знань. Зроблено висновок про існуючі зміни в оцінюванні знань студентів.

Ключові слова: педагогічний контроль, тестові технологї, функцї контролю, педагогічний тест, критерії оцінювання тестів.

Процес європейської інтеграції все більше впливає на розвиток вищої освіти України, яка чітко визначила орієнтири на входження в освітній і науковий простір Європи, удосконалюючи освітню діяльність в контексті європейських вимог. Необхідність змін у підходах до підготовки майбутніх учителів визначено у документі "Національна стратегія розвитку освіти в Україні на 2012-2021 роки", де одним із ключових напрямів державної освітньої політики є визначення реформування системи освіти - оновлення структури, змісту, організації та вдосконалення підготовки майбутніх учителів та підвищення вимог до володіння та використання в освітньому процесі сучасних інформаційних технологій та можливостей мережі Інтернет. Проте одним із найважливіших показників $€$ рівень знань студентів 3 навчальних дисциплін. Контроль знань, умінь проходить через увесь процес навчальної діяльності, але особливого значення набуває після вивчення якого-небудь розділу програми або завершення навчання.

Функції контролю розглядаються в багатьох працях 3 педагогіки та методики, авторами яких $€$ Є.І.Перовський, Н.Г.Дайрі, Г.І. Казьмін, Т. С. Панфілова, М. М. Покровська, Н. Є. Анкудінова, М. Т. Калінчук та інші.

Питання теорії і методології педагогічного контролю на основі тестової технології розглядали такі науковці, як: В. С. Аванесов, В. П. Безпалько, Н. В. Козленкова, А. І. Майоров, О. А. Рикова, Л. О. Федотова тощо.

Мета статті полягає в розкритті питання організації педагогічного контролю знань студентів на основі тестової технології.

До концептуальних характеристик якості національної освіти, окреслених у нормативно-правових документах віднесено такі положення [12]:

- якість освіти є національним пріоритетом;

- висока якість освіти передбачає органічний зв'язок освіти і науки, педагогічної теорії і практики; 
- модернізація системи освіти спрямована на забезпечення ії якості, відповідно до найновіших досягнень вітчизняної і світової науки, культури та соціальної політики.

Узагальнюючи різні погляди на функції контролю, можна виділити такі її складові [2], [3], [8]:

- освітня: забезпечується систематизація знань студентів, коригування результатів їхньої навчальної діяльності;

- виховна: полягає у формуванні моральних якостей студентів, вихованні адекватної самооцінки, дисциплінованості, самостійності, почуття відповідальності та обов'язку; залучення студентів до взаємоконтролю, сприяє формуванню в них принциповості, колективізму та взаємоповаги;

- розвивальна: забезпечується фрормування самостійності, критичності та логічності мислення студента, зокрема, уміння аналізу та синтезу, порівняння та узагальнення, абстрагування та конкретизації, класифікації та систематизації; розвивається пам'ять, удосконалюється мислительна діяльність;

- діагностична: полягає у визначенні рівня та якості знань, умінь та навичок, у виявленні прогалин у знаннях і вміннях та їх причин, визначає заходи для підвищення якості навчання, попередження і подолання неуспішності;

- стимулююча: полягає в спонуканні студентів до систематичної праці, отримання кращих результатів у навчанні, подолання прогалин у знаннях; добре вмотивована та справедлива оцінка успішності того, хто навчається, $є$ важливим стимулом у навчальній діяльності, який переростає у стійкий мотив обов'язку та відповідальності;

- прогностична: полягає у визначенні напряму та мети роботи на кожному етапі навчальної діяльності для підвищення ефективності навчання та пізнавальної діяльності студентів;

- оцінювальна: передбачає співставлення виявленого рівня знань, умінь і навичок з вимогами навчальної програми, вона несе в собі велике виховне навантаження, оскільки в ній закладений стимул, під дією якого у студентів, формується стремління до навчання та мотив пізнання;

- управлінська (коригуюча): передбачає коригування роботи студентів і власної діяльності викладача, тобто зміни методики навчання, удосконалення організації навчання.

Крім того, контроль повинен задовольняти таким принципам [3, с. 236238]: об'єктивність, систематичність, наочність, диференційованість, індивідуальний характер. Об'єктивність контролю означає, що результати оцінювання співпадають незалежно від методів і засобів контролювання та викладача, який здійснював даний контроль. Вимога принципу систематичності полягає в необхідності здійснення контролю на всіх етапах навчального процесу - від початкового сприймання знань і до їх практичного використання. Крім того, повинен здійснюватися комплексний підхід до діагностування, при якому різноманітні форми, методи і засоби контролю використовуються в тісному взаємозв'язку та єдності, підпорядковуючись одній меті. Принцип наочності полягає в проведенні відкритого контролю всіх студентів за однаковими критеріями, а також обговорення та аналізу його 
результатів. Диференційованість вимагає більш-менш розгалужену градацію оцінок успішності (балів), оскільки різні студенти працюють по-різному, мають неоднакові здібності та можливості (наприклад, наявність або відсутність вільного доступу до комп'ютерної техніки). Індивідуальний підхід під час проведення контролю означає, що необхідно перевіряти знання, уміння та навички кожного студента, при цьому враховуючи його індивідуальні особливості: темперамент, характер, здібності, нахили, мотиви, особливості психічних фуункцій [3, с. 236-238].

Залежно від місця застосування в навчальному процесі та дидактичної мети прийнято виділяти попередній, поточний, тематичний (модульний), підсумковий контроль і самоконтроль.

Попередній контроль призначений, в основному для діагностування. Він проводиться, як правило, на початку навчання нової дисципліни або нового розділу з метою виявлення того запасу знань, який студенти мають на даний час відносно питань, що будуть розглядатись. У ході цієї перевірки визначаються загальна підготовленість студентів, рівень володіння вихідними поняттями тієї дисципліни, вивчення якої вони розпочинають. У процесі попереднього контролю мобілізуються знання студентів, їх особистий досвід, визначається матеріал для повторення, відбувається "вирівнювання знань", що передує роботі над новим матеріалом. Зокрема, починаючи вивчення різних розділів навчальних курсів для студентів доцільно провести попередній контроль з метою виявлення рівня попередніх знань.

Провівши попередній контроль, викладач може визначити рівень подання певних тем або розділів, хто із студентів потребує окремої уваги з боку викладача та його допомоги, а хто більш складних та творчих завдань. Отже, попередній контроль передбачає ознайомлення викладача з успішністю студентів за попередній період та їхнім рівнем розвитку. Усе це дозволяє викладачеві раціонально та ефрективно організувати процес навчання.

Поточний контроль знань $є$ органічною частиною всього педагогічного процесу i слугує засобом виявлення ступеня засвоєння навчального матеріалу. Управління навчальним процесом можливе лише на підставі даних поточного контролю. Основна мета поточного контролю - забезпечення зворотного зв'язку між викладачем та студентами в процесі навчання, перевірка їх готовності до виконання наступних навчальних завдань, а також забезпечення управління їх навчальною мотивацією [2, с. 116]. Відомості, отримані під час поточного контролю, використовуються для коригування методів і засобів навчання, а також для самостійної роботи студентів. Завдання поточного контролю зводяться до того, щоб [2, с. 117]:

- виявити обсяг, глибину та якість сприйняття та засвоєння матеріалу, що вивчається;

- визначити недоліки в знаннях і намітити шляхи їх усунення;

- виявити ступінь відповідальності студентів і ставлення їх до роботи, встановивши причини, які перешкоджають їх роботі;

- виявити рівень опанування навичок самостійної роботи і намітити шляхи і засоби їх розвитку;

- стимулювати інтерес студентів до предмета та їх активність у пізнанні. 
Узагальнюючи сказане, можна відмітити, що головне завдання поточного контролю - допомоги студентам організувати свою роботу, навчитися самостійно, відповідально та систематично вивчати навчальний предмет. Поточний контроль може проводитися у формі усного (індивідуального чи фронтального) або письмового опитування під час проведення навчальних занять, візуального контролю за виконанням завдання, а також у вигляді комп'ютерного тестування. Поточна перевірка забезпечує повноту та міцність засвоєння знань, а також їх системність - міцний зв'язок нових уявлень і понять у свідомості студента зі знаннями, що набуті раніше.

Тематичний контроль пов'язаний із перевіркою рівня знань, умінь та навичок студентів у межах певного розділу чи великої теми конкретної навчальної дисципліни. Основною метою тематичного контролю є перевірка та оцінювання знань студентів з кожної логічно завершеної частини навчального матеріалу (теми або розділу).

Модульний контроль - це контроль знань студентів після вивчення модуля навчальної дисципліни. Модульний контроль може проводитися у формі контрольної роботи, тестування, виконання контрольних завдань тощо. Модульний контроль $є$ необхідним елементом модульно-рейтингового контролю якості засвоєння студентами змісту навчання.

В умовах запровадження кредитно-модульної системи організації навчального процесу основна увага приділяється рівню якості знань майбутніх вчителів. У зв'язку з цим постає проблема використання інноваційних діагностичних методик моніторингу освіти. Такою основною формою перевірки знань, умінь і навичок студентів, зокрема майбутніх учителів технологій, $\epsilon$ тестування. Тестовий контроль є основним видом контролю, що забезпечує стабільність вимог до очікуваних досягнень студентів, відповідність процесу навчання освітнім стандартам в умовах демократизації та інформатизації навчання.

Існують різні визначення педагогічного тесту, що підкреслює різні значущі грані тестування. За В.І. Лозовою і Г. В. Троцко "тест у вузькому значенні розуміється як короткочасний, технічно просто поставлений експеримент, комплекс завдань, що відповідають змісту навчання і забезпечують виявлення ступеня оволодіння навчальним матеріалом" [6]. В. С. Аванесов визначає педагогічний тест як “...систему завдань зростаючої трудності, специфічної форми та визначеного змісту - систему, яку створено з метою об'єктивного, якісного та ефективного методу визначення структури та вимірювання рівня підготовленості" [1, с. 190].

На думку К. Інгекампа, під тестуванням розуміється метод педагогічної діагностики, за допомогою якого вибір поведінки, що презентує передумови або результати навчального процесу, повинен максимально відповідати принципам зіставлення, об’єктивності, надійності та валідності вимірів [4].

Таким чином педагогічний тест - це така система завдань результат виконання, яких групою претендентів дозволяє досить надійно ранжувати якістю навчання, кількістю наявних знань; система стандартизованих завдань, результат виконання яких дозволяє за заданим ступенем точності виміряти знання навички та вміння випробовуваного [5, с. 52]. 
Педагогічні тести ґрунтуються на меті тестування та залежать від етапу навчання, на якому воно проводиться (рис. 1).

\section{ПЕДАГОГТНН ТЕСТИ}

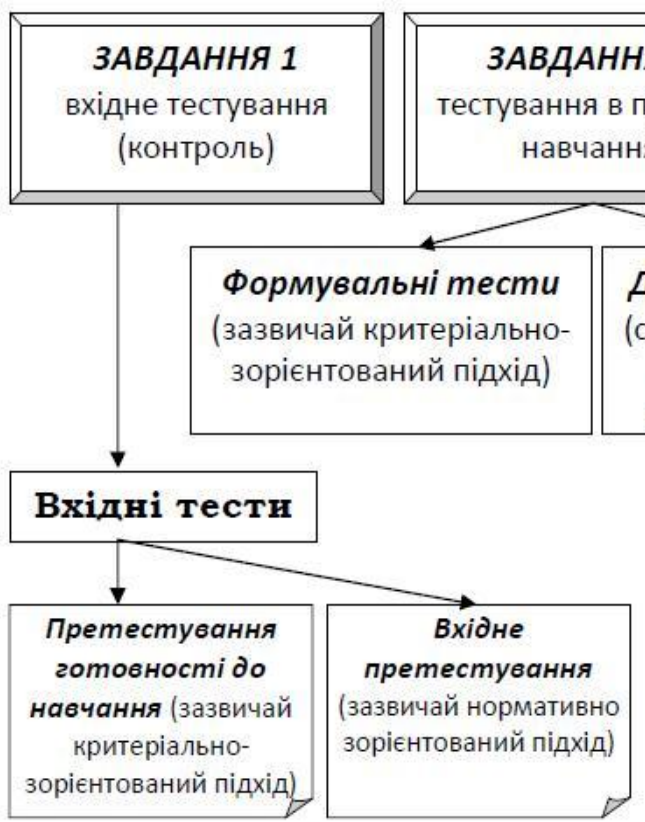

\section{ЗАВДАННЯ 3}

результуюче

(вихідне) тестування

Рис. 1. Педагогічні тести залежно від мети тестування

Порівняно з традиційними методами тестова форма контролю має цілу низку переваг [9, с. 86-90]:

- універсальність, оскільки може використовуватися на всіх етапах навчального процесу;

- охоплюється контролем великий обсяг матеріалу;

- зменшується порівняно з традиційним опитуванням витрати часу приблизно на 50 відсотків;

- реалізується можливість для впровадження модульного навчання та системи рейтингового контролю;

- підвищується об'єктивність оцінювання знань;

- стимулюється дія на пізнавальну діяльність студентів та учнів;

- контролюється велика кількість теоретичних питань;

- виключається негативна дія на результати тестування таких фракторів, як настрій, рівень кваліфікації та інші характеристики конкретного викладача; техніки;

- орієнтується на сучасні технічні засоби, на використання комп'ютерної

- дає можливість викладачеві швидко зрозуміти, як далі працювати 3 конкретним студентом, а також допомагає лектору скоректувати курс.

Застосування тестової технології, як методу вимірювання призвело до появи та використання великої кількості різноманітних тестів. Це зумовило необхідність їх класифікації. У сучасній дидактиці існують різні підходи до класифікації тестів. 
Вона здійснювалась за різними критеріями та принципами багатьма фахівцями, серед яких А. Аванесов, А. Анастазі, І.Булах, В. Безпалько, О. Киверялг, Н. Павлюкова, М. Розенберг, Т. Рюттер, І. Солуха та ін.

Як зазначає І. В. Солуха, досконалості тестовий метод набуває у вигляді комп'ютерного тестового контролю результатів навчального процесу. Комп'ютерний тестовий контроль $€$ важливою складовою нових інформаційних технологій навчання, які поступово і впевнено втілюються у педагогічну практику [10, с. 3].

Так Н.Ф. Павлюкова виділяє чотири основні групи тестів за рівнем складності: репродуктивний тест, тест на використання набутих знань, творчий тест та проблемний тест [7].

Т. Рюттер розрізняє три класи тестових завдань:

а) відкриті - відповідь задана і тому, хто тестується, і тому хто опрацьовує результати тестування;

б) напівзакриті - відповідь відома тільки тому хто опрацьовує результати тестування;

в) закриті - відповідь не відома ні тому, хто тестується, ні тому хто опрацьовує результати тестування [13].

Найпоширенішою $є$ узагальнена класифрікація, яка на думку авторів найбільш однорідно структурована, і за якою класи тестів згруповано за однією певною ознакою рис. 2 [5].

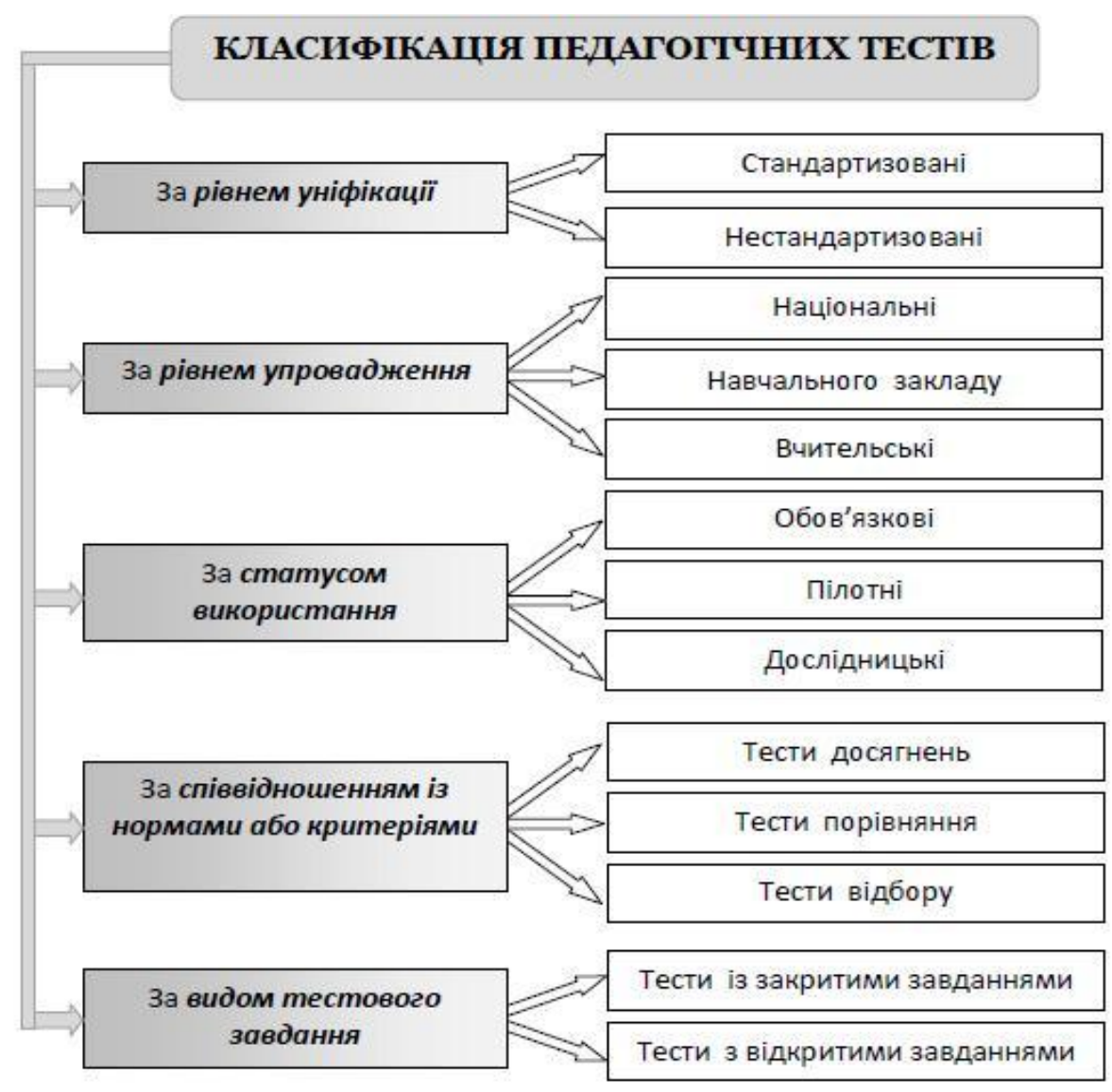

Рис. 2. Класифікаиія педагогічних тестів. 
Правильно розроблені тестові завдання перевіряють всю пізнавальну сфреру, яка містить знання, розуміння, застосування, аналіз, синтез, оцінювання.

Перш, ніж складати тести викладач повинен проаналізувати матеріал i виділити ті блоки, які будуть перевірятися методом тестового контролю. Саме викладач формує еталонні вимоги до теоретичних знань і практичних навичок до кожного блоку навчального матеріалу [11].

Приступаючи до розробки тестових завдань, необхідно враховувати:

- лише тестові вимірювання рівня знань і умінь з любої дисципліни не можуть свідчити про якість методичної підготовки майбутніх учителів;

- тільки синтез результатів процедур якісного і кількісного аналізу може дати найбільш наближену картину розподілу студентів за рівнями їх підготовки до використання предметних компетентностей в професійній діяльності;

- застосування лише тестів не дає можливості виявити розумові здібності майбутніх учителів та виявити зрушення у їх розвитку;

- зміст тестових завдань має бути таким, щоб забезпечував реалізацію ключових фуннцій педагогічних тестів: діагностичної, спрямованої на виявлення стану теоретичної підготовки; навчальної, яка виявляється у систематизації навчального матеріалу шляхом розробки тестів відповідного змісту, сприянні диференціації процесу навчання; виховної, пов'язаної з можливістю застосовувати тестові завдання для самоконтролю i самонавчання студентів; організуючої, що виявляється в активізації дій студентів і викладача, їх спонуканні до підвищення результативності своєї діяльності через незалежний характер ії оцінювання;

- під час розробки тестових завдань мають дотримувались принципи: конгруентності - відповідності змісту тесту змісту навчальної дисципліни; репрезентативності - максимального відображення в тестових завданнях змісту навчальної дисципліни; значимості - включення до тестів лише тих завдань, які відображають базові знання та уміння; наукової вірогідності включення до тестів питань такого змісту, які вважаються вірогідними і наукового обґрунтованими.

- критерії оцінювання тестів мають узгоджуватись із болонською i вітчизняною системами оцінювання і відповідати трьом загальноприйнятим у практиці вищої школи рівням навчальних досягнень: високому, середньому $\mathrm{i}$ низькому (таблиця 1).

Таблиця 1

\begin{tabular}{|l|l|l|}
\hline \multicolumn{1}{|c|}{ Рівні } & \multicolumn{1}{|c|}{ Бали } & \multicolumn{1}{|c|}{ Критерії оцінювання } \\
\hline \hline Високий & $\begin{array}{l}26-30=\mathrm{A} ; \\
21-25=\mathrm{B}, \mathrm{C} ;\end{array}$ & $\begin{array}{l}\text { 1. Знання повні, системні, усвідомлені й міцні. } \\
\text { 2. Студенти самостійно вибирають систему дій у різних } \\
\text { ситуаціях, переносять їх на інші види діяльності. }\end{array}$ \\
\hline Середній & $15-20=\mathrm{D}, \mathrm{E}$ & $\begin{array}{l}\text { 1. Студенти володіють матеріалом частково. Знання } \\
\text { 3 предмету неповні. } \\
\text { 2. Володіють умінням виконувати дії за взірцем, } \\
\text { допускають помилки при перенесенні ї на інші } \\
\text { види діяльності. }\end{array}$ \\
\hline
\end{tabular}




\begin{tabular}{|c|c|c|}
\hline Рівні & Бали & Критерії оичінювання \\
\hline Ниизький & 1-14=F,FX & $\begin{array}{l}\text { 1. Студенти мають окремі знання з предмету. } \\
\text { 2. Вміють відтворювати дії за взірцем при допомозі } \\
\text { викладача, переносити їх на інші види діяльності не } \\
\text { вміють. }\end{array}$ \\
\hline
\end{tabular}

При складанні тестів різного рівня необхідно розрахувати термін для їхнього виконання, виходячи зі складності тестів.

Висновки. Отже, тестова система оцінювання знань відображає глибину засвоєння навчального матеріалу, забезпечує об'єктивність та індивідуальний підхід в оцінюванні рівня сформованості знань і якості навчання кожного студента як особистості, стимулює студентів до активної самостійної роботи в оволодінні профеесійно значущими знаннями.

Завдання закладів вищої освіти - зробити контроль рівня знань студентів передбачуваним, обов'язковим, правильним, що стимулює до більш змістовного і глибокого вивчення дисципліни, до творчого пошуку.

\section{Використана література:}

1. Аванесов В. С. Компютеризация тестових заданий. Москва : Центр тестирования, 2002. 240 с.

2. Галузяк В. М., Сметанський М. І., Шахов В. І. Педагогіка [Текст] : навч. посібник. Вінниця : Вінницька обласна друкарня, 2001. 200 с.

3. Зайченко I. В. Педагогіка [Текст] : навч. посіб. для студ. вищих пед. навч. закл. Чернігів : Деснянська правда, 2003. 528 с.

4. Ингекамп Карлхайнц. Педагогическая діагностика : научное издание / пер. Н. М. Рассказова. Москва : Педагогика, 1991. 240 с.

5. Кухар Л. О., Сергієнко В. П. Конструювання тестів. Курс лекцій : навч. посіб. Луцьк, 2010. 182 с.

6. Лозова В. І., Троцко Г. В. Теоретичні основи виховання і навчання : навчальний посібник. Харків : "OBC", 2002. 400 c.

7. Павлюкова Н. Ф. Діагностика якості навчання учнів при організації різноманітних форм контролю знань на уроках біології [Електронний ресурс]. Режим доступу: 05.05.2019: <http://www.rusnauka.com/2._SND_2007/Pedagogica/19210.doc.htm >.

8. Педагогіка [Текст] / под ред. Ю. К. Бабанского. Москва : Просвещение, 1983. 608 с.

9. Смирнов С. Д. Педагогика и психология высшего образования: от деятельности к личности. [Текст] : уч. пособ. Москва : Академия, 2001. 304 с.

10. Солуха I. В. Тестовий контроль у процесі навчання фізики (на матеріалі теоретичної фізики): автореф. дис. ... канд. пед. наук: спец. 13.00.02. Київ : Нац. пед. ун-т ім. М. П. Драгоманова, 1999. $19 \mathrm{c}$.

11. Трегубова Г. М. Методологічні основи організації тестового контролю знань студентів. Вісник НТУУ “КПГ”. Філософія. Психологія. Педагогіка : збірник наукових праць. 2007. № 2(20). Ч. 1. C. 139-143.

12. Указ Президента України від 17 квітня 2002p. № 347 “Про Національну доктрину розвитку освіти" // У кн.:Законодавчі акти України з питань освіти. Київ : Парламентське вид-во, 2004.

13. Rutter M, Pickles A, Murray R, Eaves L. Testing hypotheses on specific environmental causal effects on behavior. Psychological Bulletin. 2001 May;127(3), 291-324.

\section{References:}

[1] Avanesov V. S. Kompyuterizaciya testovih zadanij. Moskva : Centr testirovaniya, 2002. $240 \mathrm{s.}$

[2] Haluziak V. M., Smetanskyi M. I., Shakhov V. I. Pedahohika [Tekst] : navch. posibnyk. Vinnytsia : Vinnytska oblasna drukarnia, 2001. $200 \mathrm{~s}$.

[3] Zaichenko I. V. Pedahohika [Tekst] : navch. posib. dlia stud. vyshchykh ped. navch. zakl. Chernihiv : Desnianska pravda, 2003. $528 \mathrm{~s}$. 
[4] Ynhekamp Karlkhaints. Pedahohycheskaia diahnostyka : nauchnoe yzdanye / per. N. M. Rasskazova. Moskva : Pedahohyka, 1991. 240 s.

[5] Kukhar L. O., Serhiienko V. P. Konstruiuvannia testiv. Kurs lektsii : navch. posib. Lutsk, 2010.182 s.

[6] Lozova V. I., Trotsko H. V. Teoretychni osnovy vykhovannia i navchannia : navchalnyi posibnyk. Kharkiv : "OVS", 2002. 400 s.

[7] Pavliukova N. F. Diahnostyka yakosti navchannia uchniv pry orhanizatsii riznomanitnykh form kontroliu znan na urokakh biolohii [Elektronnyi resurs]. Rezhym dostupu : 05.05.2019: <http://www.rusnauka.com/2._SND_2007/Pedagogica/19210.doc.htm >.

[8] Pedagogika [Tekst] / pod red. Yu. K. Babanskogo. Moskva : Prosveshenie, 1983. 608 s.

[9] Smirnov S. D. Pedagogika i psihologiya vysshego obrazovaniya: ot deyatelnosti k lichnosti. [Tekst] : uch. posob. Moskva : Akademiya, 2001. 304 s.

[10] Solukha I. V. Testovyi kontrol u protsesi navchannia fizyky (na materiali teoretychnoi fizyky): avtoref. dys. ... kand. ped. nauk: spets. 13.00.02. Kyiv : Nats. ped. un-t im. M. P. Drahomanova, 1999. 19 s.

[11] Trehubova H. M. Metodolohichni osnovy orhanizatsii testovoho kontroliu znan studentiv. Visnyk NTUU “KPI”. Filosofiia. Psykholohiia. Pedahohika : zbirnyk naukovykh prats. 2007. № 2(20). Ch. 1. S. 139143.

[12] Ukaz Prezydenta Ukrainy vid 17 kvitnia 2002r. № 347 "Pro Natsionalnu doktrynu rozvytku osvity" // U kn.:Zakonodavchi akty Ukrainy z pytan osvity. Kyiv : Parlamentske vyd-vo, 2004.

[13] Rutter M, Pickles A, Murray R, Eaves L. Testing hypotheses on specific environmental causal effects on behavior. Psychological Bulletin. 2001 May;127(3), 291-324.

ШЕВчУКЛ.Д., ЯШАНов С.Н. Теоретические и методологические аспекты педагогического контроля знаний студентов на основе тестовой технологи.

В статье рассмотрен вопрос теории и методологии педагогического контроля знаний студентов на основе тестовой технологии. Обоснованы рекомендации относительно организации процесса тестового контроля знаний. Подчеркнуто, что тестовые технологии заслуживают особенного внимания, ведь это эффективный способ проверки уровня качества знаний студентов. Поданы предложения относительно решения проблемы качества контроля знаний. Сделан вывод о существующих изменениях в оченивании знаний студентов.

Ключевые слова: педагогический контроль, тестовые технологии, функиии контроля, педагогический тест, критерии оценивания тестов.

SHEVCHUK L. D., YASHANOV S. N. Theoretical and methodological aspects of pedagogical control of knowledge of students on the basis of test technologists.

The article deals with the issues of the theory and methodology of pedagogical control of students' knowledge on the basis of test technology. The recommendations for organizing the process of test control of knowledge are substantiated. It is emphasized that test technology deserves special attention, as it is an effective way to check the level of student knowledge. Proposals for solving the problem of quality control of knowledge are presented. A conclusion is drawn about existing changes in the assessment of students' knowledge.

Keywords: pedagogical control, test technologies, control functions, pedagogical test, test evaluation criteria. 